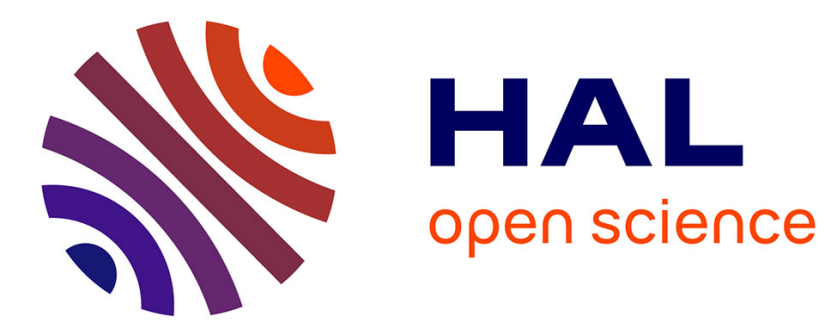

\title{
Political Social Media in the Global South
}

Joyojeet Pal, Andre Gonawela

\section{To cite this version:}

Joyojeet Pal, Andre Gonawela. Political Social Media in the Global South. 15th Conference on e-Business, e-Services and e-Society (I3E), Sep 2016, Swansea, United Kingdom. pp.587-593, 10.1007/978-3-319-45234-0_52 . hal-01702140

\section{HAL Id: hal-01702140 \\ https://hal.inria.fr/hal-01702140}

Submitted on 6 Feb 2018

HAL is a multi-disciplinary open access archive for the deposit and dissemination of scientific research documents, whether they are published or not. The documents may come from teaching and research institutions in France or abroad, or from public or private research centers.
L'archive ouverte pluridisciplinaire HAL, est destinée au dépôt et à la diffusion de documents scientifiques de niveau recherche, publiés ou non, émanant des établissements d'enseignement et de recherche français ou étrangers, des laboratoires publics ou privés. 


\title{
Political Social Media in the Global South
}

\author{
Joyojeet Pal ${ }^{1}$, Andre Gonawela ${ }^{1}$ \\ ${ }^{1}$ University of Michigan \\ \{joyojeet, andregon\}@umich.edu
}

\begin{abstract}
We examine the evidence of growing social media use among political elites in low- and middle-income countries, including in places where the proportion of actual voters on social media is small. We propose three ways to view this phenomenon of- first, as signaling, second, as a means for politicians to access elite populations, and third as a way to circumvent mainstream media and exercise direct control over political communication.
\end{abstract}

Keywords: Twitter, Social Media, Political Communication, Global South

\section{Introduction}

In the last decade, engagement with major social media outlets such as Twitter and Facebook has become a central element of political communication, particularly around major elections. Social media have challenged media logics in several parts of the world, most recently in the United States, where politicians have been able to reach citizens directly and even channel their mainstream media engagements through social media. Although scholarly attention to political social media has drawn its empirical basis in developments in the Western world, the trend of social media use is now global. The World Bank lists 135 countries as low- and middle-income, and the Twiplomacy study found social media use among politicians in 119 of those countries, including in 25 of the 31 low-income countries [1]. At the same time, despite claims that social media drive election results [2] there is little evidence that social media influence election outcomes, and indeed evidence suggests that online popularity can be deeply misleading in predicting results [3]. Events around the Egyptian pro-democracy movement and election-related protests in Iran were early drivers on subjects of social media and citizen action in the Global South $[4,5]$. Commentary on social media has since taken a cautionary tone, noting its purpose as a means for media capture by entrenched institutions and powers [6-8]. We propose a lens to approach the motivations of political actors for whom social media use is not a means of winning elections but is nonetheless an important media strategy.

\section{Approach}

We identified 73 nations listed as low- and middle-income where the head of government had a verified account on Twitter or Facebook. In each of these, we searched, where relevant, for at least one known electoral opposition figure. Overall, we gathered the details of 113 politicians - including their date of joining social media and scale of following. Our goal here is not to analyze the tweets in detail but rather to document the broad use of social media, so we primarily gathered basic data 
on rate of messaging, duration on social media, and online following. We also kept a database of the 3,200 recent tweets (till May2016) of politicians with more than 1 million followers, and we conducted a discourse analysis of the tweet content to qualitatively observe the language in the messaging. Rather than provide a comprehensive account of social media use in low- and middle-income countries, our purpose here is to propose reasons for its presence and potential growth. Since Tweets are typically mirrored as Facebook updates, we focused primarily on public Twitter data, using Facebook only for illustrative purposes.

\section{Findings}

Fifty-three of the politicians had active accounts on both Facebook and Twitter, 27 had a following of 1 million or more on either Twitter or Facebook, and 14 had a following of more than 1 million on both Facebook and Twitter. Some leaders such as Enrique Peña Nieto of Mexico and Najib Razak of Malaysia were early adopters, getting on social media prior to the extremely successful Obama campaign of 2008. The majority of politicians in our sample have joined social media since 2009. Some of the most recent accounts include those of Jimmy Morales of Guatemala, José Serra of Brazil, Abdel Fatah al-Sisi of Egypt and Muhammadu Buhari of Nigeria, each of whom had more than 500,000 followers on Twitter within a year of joining.

Table 1. Selected highly followed political figures as proportion of national internet penetration (min followers:150,000).

\begin{tabular}{crlrr}
\hline Country & \multicolumn{1}{c}{$\begin{array}{l}\text { Internet } \\
\text { users } \\
\text { ('000) }\end{array}$} & $\begin{array}{c}\text { Political figure } \\
(*=\text { head of govt.) }\end{array}$ & $\begin{array}{c}\text { Facebook } \\
\text { Likes } \\
\text { ('000) }\end{array}$ & $\begin{array}{c}\text { Twitter } \\
\text { Followers } \\
\text { ('000) }\end{array}$ \\
\hline Jordan & 3,200 & Rania Al Abdullah & 5,623 & 4,480 \\
Myanmar & 1,118 & Aung San Suu Kyi* & 1,715 & 0 \\
Cambodia & 1,362 & Sam Rainsy & 2,063 & 0 \\
Afghanistan & 1,955 & Ashraf Ghani* & 1,046 & 171 \\
Rwanda & 1,248 & Paul Kagame* & 515 & 1,340 \\
Guatemala & 3,620 & Jimmy Morales & 925 & 52.5 \\
Costa Rica & 2,407 & Luis Solís* & 600 & 179 \\
Iraq & 3,815 & Haider Al-Abadi & 914 & 65.2 \\
Indonesia & 42,727 & Prabowo Subianto & 9,080 & 2,380 \\
Turkey & 38,216 & Recep Erdoğan* & 8,048 & 7,720 \\
Pakistan & 25,136 & Imran Khan & 5,237 & 3,300 \\
Haiti & 1,176 & Michel J. Martelly* & 201 & 142 \\
Ecuador & 6,767 & Rafael Correa* & 1,141 & 2,540 \\
\hline
\end{tabular}

In Table 1, the politicians in our sample with the highest number of either Facebook likes or Twitter followers, as a ratio of the number of internet users in their home country, are arranged in descending order, to allow a snapshot into popularity trends. Domestic internet use is not necessarily a reliable value to peg a political leader's popularity against (we also have no way of telling whether these likes or follows are authentic). From the sample of accounts with more than 1 million followers, we find that fame independent of politics can be useful for candidates -thus Imran Khan of Pakistan, Morales of Guatemala, and Michel Martelly of Haiti 
gain followers for their other activities (cricket, comedy, music). Reach on social media can reflect the potential media footprint that politicians control, as is visible among the nation-states with a relatively smaller internet penetration such as Afghanistan, Niger and Cambodia, where a leader can dominate the local social media following. Even among countries with large and diverse social media use, politicians can directly reach upward of $10 \%$ of their countries' entire populations Recep Erdoğan of Turkey, Luis Solís of Costa Rica, and Rafael Correa of Ecuador all command a social media following that crosses this threshold.

Politicians' sphere of influence may extend beyond the regional boundaries of their nation-states, such as in the case of countries with large diaspora populations such as Cambodia, Vietnam and Guatemala. We see a spectrum of political systems - while in 28 countries, electoral issues are arguably crucial (both the elected leader and the most recent major opposition leader have presences), there are also leaders from single-party systems like Paul Kagame of Rwanda and Nguyễn Tấn Dũng of Vietnam who are online despite limited electoral opposition in their respective nations.

\section{Why Social Media?}

Based on our study of language of the tweets, we identify three recurrent themes in the politicians' social media messaging. The first is signaling - i.e. what the brand of social media suggests about the kind of politician standing behind it. The second is elite access - i.e. reaching out to elite populations in a country or in the world who respond to social media. The third is media logic - i.e. creating channels to circumvent the mainstream media to reach citizens directly.

\subsection{Signaling}

Social media exist as an outward brand presence. India's Narendra Modi is Asia's most followed politician, Rwanda's Kagame is Africa's. The two leaders use discussions around development as signaling for what their respective regimes stand for. Both leaders have complicated political histories - Modi was known for his involvement in religious riots in India, and Kagame has run Rwanda without credible opposition for more than two decades. On Twitter, both propose images of tech-savvy modernists, re-creating political images around a discourse more directly controlled by their teams than by mainstream media.

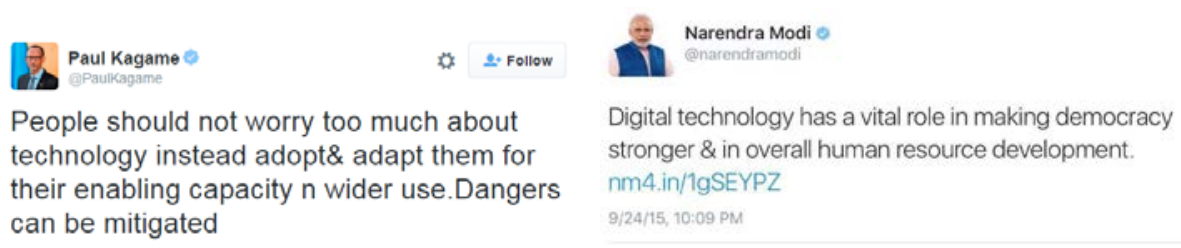

Fig 1. Twitter messages from Rwandan President Paul Kagame and Indian Prime Minister Narendra Modi

The two tweets in Figure 1 exemplify this spirit. The messages are crafted as aphorisms that use aspirational language but are delivered as enlightened counsel. The speakers emerge as leaders who appreciate modernity. In Rwanda's case, the message 
underlines the need for a continuing Kagame regime. In India, Modi's message nods at an aspirational discourse around technology and development for a rising India.

Although there is a broad literature on political communication and the role of the internet in political branding [9], little work looks at the Global South. The more complex question - that of how the association with the technology artifact is seen as playing a role in building positive online capital for a political leader - lies at the intersection of communications and development studies. There is also little work on political signaling in the Global South, and much of the existing work around traditional image management of former (or current) strongmen through signaling neoliberal reforms, tourism, etc., has been critiqued for its overt courting of Western approval [10]. Politicians' use of social media in these settings opens up the possibilities of examining the content of their social signaling, the nature of its spread, as well as theoretical work on what the technology artifact means to the political brand. Such work builds upon a wealth of research into aspiration in technology that has interrogated what technology artifacts themselves come to represent for modernity [11], and how these have impacted geopolitical discourses [12].

\subsection{Elite Affiliation}

Because social media access is restricted largely to the educated wealthy in the Global South, these media are more likely to reach an elite demographic both within countries and in the diaspora. The imagination of social media as a technology associated with the West and with the younger generations can extend to the political branding of the user and who the user appeals to. Pakistani politician Imran Khan, himself critiqued as a Cambridge-educated elite, has been credited with reaching the otherwise apolitical "burger population" (young Americanized Pakistanis) with the use of social media, compensating for weaker grass-roots organization compared to the major Pakistani parties. Social media here offer an alternative and arguably complementary means of outreach that might not have the same electoral draw as grass-roots presence but creates value by attracting the attention of mainstream media.

$$
\text { Imran Khan @ImranKhanPTI }
$$

Interesting piece on Pak's "burger" youth \& how PTI

mobilised them into mainstream politics aje.io/xIvx
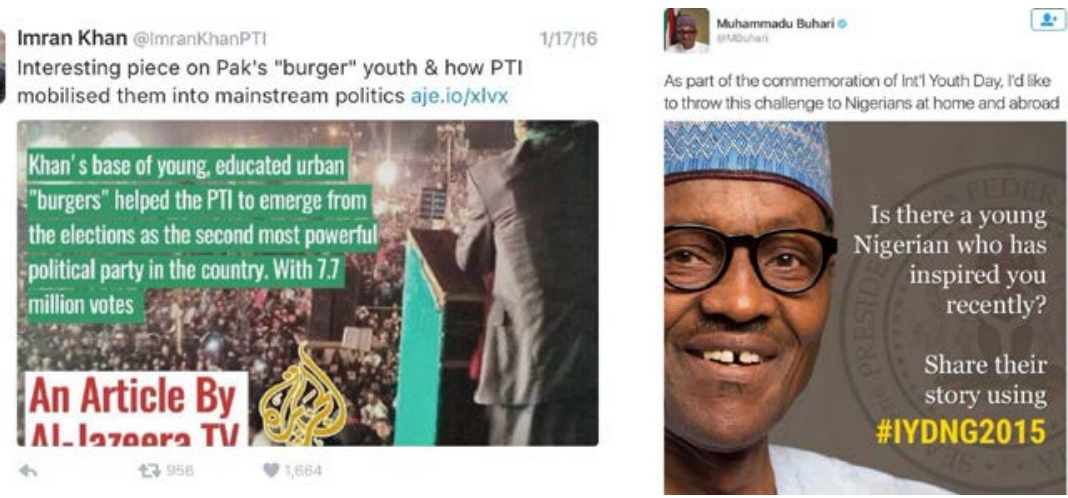

Fig 2. Twitter message from Pakistani cricketer and opposition politician Imran Khan and Nigerian President Muhammadu Buhari 
Besides wealthy expatriates, the elite access of social media also extends to young voters. In Pakistan, the ruling party is represented on social media not by the prime minister but by his young daughter, who posts messages as well as pictures of her father, Nawaz Sharif, at various events. Social media are used as a means of performing filial duty while also emphasizing the leader's anointed nod to the technology and aspirations of younger Pakistanis. Young voters have traditionally not been a useful political constituency in many countries because of apathy, but these cases suggest that political actors see the potential to change this culture. The tweet from former military coup leader and Nigeria's current President Buhari (Figure 2) has three nested messages: first, by posting first-person messages on Twitter he signals a social media user challenging opponents' claim that he has never finished school; second, his message reaches out to the younger voters, not a natural constituency for him, being part of an older generation with ties to military dictatorship; finally, he shouts out to Nigerians abroad - signaling that he stands not for his tribal affiliations (a major factor in elections) but for a pan-regional identity.

\subsection{Media Logic}

Studies of social media in the Global South have generally been enthusiastic about its potential for democratizing, drawn in part by events surrounding the Arab Spring [13]. Less attention has been paid to the potential for institutional capture of social media - which we see early signs of here in the massive reach of some political leaders in their home countries. Social media create a means for politicians to avoid the media logics that would dictate that only those messages seen as interesting to the mainstream media would find voice in their channels [14]. With increasingly ubiquitous access to mobile devices, a tech-savvy politician can craft a media flow straight to the citizenry. Politicians need not ignore mainstream media, which in most countries have a far more significant reach to voting citizens. Rather these politicians integrate social media channels to complement their mainstream media strategies.

Social media allow the political movement represented by a leader to be organized into one space - the same channel that serves as a voice can also serve as a means to troll or silence oppositional voices. Not only do leaders like Modi, Erdoğan, Joko Widodo of Indonesia and Noynoy Aquino of the Philippines have more followers on social media than any single mainstream media channel in their respective home states - they have all started using social media as their primary means of outreach, which in turn acts as a feeder into mainstream media. This enables politicians to better control their message and also to decide what stories they wish to give momentum to, because that power now rests in their networks.

\section{Conclusions}

Focusing primarily on messaging such as tweets restricts our understanding of the online networks of political leaders but helps us to understand the ways politicians wish to be perceived. Countries that have big enough electorates and international presence increasingly need political leaders who look "global" - this adds an externalfacing dimension to the social media that goes beyond wooing an electorate. 
There is clear evidence that political social media will stay and likely grow in much of the Global South. However, the confluence of ideas from multiple bodies of work means more than ever that an inter-disciplinary frame is needed to make sense of these developments. Politicians' use of social media to project themselves as representing a modern vision for their respective states is tied to the symbolic value of technology as a means for aspiration in the Global South, particularly as technology has become elemental to our collective perception of what constitutes development. As the next modern selfie-shooting political star turns the corner, it is imperative that the community of e-society researchers consider how our theoretical tools can help to understand the ways that political communications and indeed power relations are changing permanently as Twitter and Facebook become household names even in the places where they don't translate all that well.

\section{References}

1. Lufkens, M., Twiplomacy Study 2016, Burson-Marsteller, Editor. 2016: Geneva.

2. Barclay, F.P., et al., India 2014: Facebook 'Like'as a Predictor of Election Outcomes. Asian Journal of Political Science, 2015. 23(2): p. 134-160.

3. Leng, H.K., Marketing politicians on Facebook: an examination of the Singapore general election 2011. Studies in Business and Economics, 2012. 7(1)

4. Sabadello, M., The role of new media for the democratization processes in the Arab world. The Arab revolutions. Reflections on the role of civil society, human rights and new media in the transformation processes, SAFRAN schlaininger arbeitspapiere für friedensforschung, abrüstung und nachhaltige entwicklung, 2011: p. 11.

5. Grossman, L., Iran's protests: Why Twitter is the medium of the movement. Time, 2009. 2009.

6. Morozov, E., Iran: Downside to the "Twitter Revolution". Dissent, 2009. 56(4)

7. Mungiu-Pippidi, A. and I. Munteanu, Moldova's "Twitter Revolution". Journal of Democracy, 2009. 20(3): p. 136-142.

8. Burns, A. and B. Eltham, Twitter free Iran: An evaluation of Twitter's role in public diplomacy and information operations in Iran's 2009 election crisis. 2009.

9. Dahlgren, P., The Internet, public spheres, and political communication: Dispersion and deliberation. Political Communication, 2005. 22(2): p. 147-162.

10. Fisher, J., 'Image management' in east Africa: Uganda, Rwanda, Kenya and their donors. Images of Africa: Creation, negotiation and subversion, 2015.

11. Pal, J., Rajnikant's Laptop: Computers and development in popular Indian cinema. Information Technologies \& International Development, 2010. 6(2)

12. Burrell, J., Invisible users: Youth in the Internet cafés of urban Ghana. 2012: MIT Press.

13. Lotan, G., et al., The Arab Spring| the revolutions were tweeted: Information flows during the 2011 Tunisian and Egyptian revolutions. International Journal of Communication, 2011. 5: p. 31.

14. Vergeer, M., L. Hermans, and S. Sams, Online social networks and microblogging in political campaigning The exploration of a new campaign tool and a new campaign style. Party Politics, 2013. 19(3): p. 477-501. 
